\title{
PEMBELAJARAN MENULIS ARTIKEL OPINI BERBASIS PROYEK
}

\author{
Sakaria $^{1}$, Asdar ${ }^{2}$, Amal Akbar ${ }^{3}$ \\ ${ }^{1}$ Fakultas Bahasa dan Sastra Universitas Negeri Makassar \\ ${ }^{2}$ Fakultas Keguruan dan Ilmu Pendidikan Universitas Bosowa Makassar \\ ${ }^{3}$ Fakultas Keguruan dan Ilmu Pendidikan Universitas Muhammadiyah Makassar
}

\begin{abstract}
ABSTRAK
Tujuan yang ingin dicapai dalam penelitian ini adalah: (1) mengetahui hasil belajar mahasiswa dalam pembelajaran menulis artikel opini tanpa menggunakan model pembelajaran berbasis proyek pada pretest, (2) mengetahui hasil belajar mahasiswa dalam pembelajaran menulis artikel opini dengan menggunakan model pembelajaran berbasis proyek pada posttest, dan (3) mengetahui efektivitas model pembelajaran berbasis proyek dalam pembelajaran menulis artikel opini. Penelitian ini merupakan penelitian eksperimen dengan model true experimental design bentuk one group pretest posttest design. Untuk memperoleh data pada penelitian ini, menggunakan instrumen lembar observasi dan tes. Data analisisis dengan menggunakan statistik deskriptif dan statistik inferensial. Hasil penelitian menunjukkan bahwa: (1) hasil belajar mahasiswa dalam pembelajaran menulis artikel opini tanpa menggunakan model pembelajaran berbasis proyek pada pretest berada pada kategori tidak tuntas karena persentase hasil belajar mahasiswa yang tuntas belum mencapai standar ketuntasan hasil belajar, yakni $(\geq 85 \%$ 100\%), (2) hasil belajar mahasiswa dalam pembelajaran menulis artikel opini dengan menggunakan model pembelajaran berbasis proyek pada postest berada pada kategori tuntas karena persentase hasil belajar mahasiswa yang tuntas telah mencapai standar ketuntasan hasil belajar, yakni ( $\geq 85 \%$ - 100\%), dan (3) model pembelajaran berbasis proyek efektif digunakan dalam pembelajaran pembelajaran menulis artikel opini pada Program Studi Pendidikan Bahasa dan Sastra Indonesia Universitas Muhammadiyah Makassar karena kriteria keefektifan telah terpenuhi, yaitu nilai $t_{\text {hitung }}>$ nilai $t_{\text {tabel }}(4,779>2,04)$.
\end{abstract}

Kata Kunci: Menulis, Artikel Opini, Model Pembelajaran Berbasis Proyek. 


\section{PENDAHULUAN}

Menulis merupakan suatau kegiatan komunikasi berupa penyampain pesan (informasi) dengan menggunakan bahasa tulis sebagai alat atau medianya. Menulis menjadi sebuah proses kreatif menuangkan gagasan dalam bentuk bahasa tulis dengan tujuan memberitahu, meyakinkan, atau menghibur. Menulis diartikan sebagai kegiatan menuangkan ide/gagasan dengan menggunakan bahasa tulis sebagai media penyampai (Tarigan, 2010: 15).

Kegiatan menulis merupakan kegiatan yang menggunakan proses berpikir. Proses berpikir tersebut dilakukan dalam dua hal, yakni apa dan bagaimana cara menulis. Apa yang ditulis berkaitan dengan gagasan atau materi yang akan ditulis, sedangkan bagaimana cara menulis berkaitan dengan pengembangan gagasan. Proses menggali materi tulisan dilakukan melalui kegiatan pemilihan topik, pengumpulan bahan, perencanaan penataan tulisan, penetapan tujuan menulis, dan pengembangan gagasan. Menulis merupakan hasil ahkir dan pekerjaan merangkai kata, kalimat, dan alinea untuk menjabarkan atau mengulas topik dan tema tertentu (Finoza. 2010: 192). Keterampilan menulis merupakan kemampuan yang sangat penting untuk dikuasai oleh mahasiswa, sebab melalui kemampuan ini seorang mahasiswa akan terlatih berpikir secara kritis. Kemampuan berpikir mahasiswa ini dapat disalurkan dalam berbagai bentuk tulisan, salah satunya adalah artikel opini.

Menulis artikel opini merupakan salah satu kompetensi dasar pada mata kuliah menulis artikel opini dan esai yang diajarkan pada mahasiswa program studi Pendidikan Bahasa dan Sastra Indonesia, Fakultas Keguruan dan Ilmu Pendidikan, Universitas Muhammadiyah Makassar. Rizam (2015) menyatakan bahwa artikel opini bukan merupakan artikel ilmiah murni, melainkan sebuah karya ilmiah populer yang mengacu pada referensi-referensi pemikiran yang berlaku. Artinya, betapapun juga artikel opini tetap berangkat dari fakta-fakta yang ada yang dicetuskan alam bentuk gaagasan atau pendapat.

Dalam ruang lingkup pembelajaran menulis artikel opini pada mahasiswa studi Pendidikan Bahasa dan Sastra Indonesia, Fakultas Keguruan dan Ilmu Pendidikan, Universitas Muhammadiyah Makassar. Masalah yang dihadapi dalam pembelajaran menulis artikel opini dan artikel esai adalah: (1) Mahasiswa kesulitan menuangkan ide, gagasan, analisis dan refleksi pada tulisan artikel opini, sehingga tulisan yang mereka hasilkan kurang meyakinkan untuk dibaca, (2) Kemampuan mahasiswa dalam menulis artikel opini masih rendah, hal tersebut disebabkan model pembelajaran yang digunakan oleh dosen kurang efektif dalam mengintegrasikan antara sumber belajar dan aktivitas pembelajaran sehingga mahasiswa menjadi pasif dalam pebelajaran.

Bertolak dari realita tersebut, perlu adanya suatu solusi yang memungkinkan permasalahan dalam pembelajaran menulis artikel opini dengan menggunakan model pembelajaran yang efektif. Salah satu model pembelajaran yang dianggap efektif dan dapat mengintegrasikan antara sumber belajar dan aktivitas pembelajaran yang variatif adalah model pembelajaran berbasis proyek. Model pembelajaran berbasis proyek sebagai suatu model pembelajaran yang 
mengaitkan antara materi pembelajaran dengan masalah kehidupan sehari-hari yang akrab dengan mahasiswa, atau dengan suatu proyek (Warsono dan Hariyanto, 2012: 153). Model pembelajaran berbasis proyek dipandang sebagai salah satu model penciptaan lingkungan belajar yang dapat mendorong mahasiswa mengkonstruk pengetahuan dan keterampilan secara personal. Adanya peluang untuk menyampaikan ide, mendengarkan ide-ide orang lain, dan merefleksikan ide sendiri pada ide-ide orang lain, merupakan suatu bentuk pengalaman pemberdayaan pengetahuan (meaning making process). Selain itu, mahasiswa juga untuk mengalami tahap pembelajaran yang disebut sebagai interactive research cycle yang terdiri dari tahap pertanyaan, perencanaan, pengumpulan data, mensintesis pengetahuan, dan evaluasi. Mahasiswa, dapat menggunakan kemampuannya dalam kegiatan berpikir dan bertindak dalam proses belajar. Kemampuan penting yang dikembangkan pada diri mahasiswa di lingkungan belajar adalah kemampuan komunikasi, salah satunya melalui proses menulis artikel opini.

Sehubungan dengan pemanfaatan model pembelajaran berbasis proyek dalam pembelajaran, ada beberapa penelitian yang telah dilaksanakan sebelumnya. Penelitian yang dilaksanakan oleh Tiantong dan Siksen (2013) dengan judul The Online Project-Based Learning Model Based on Student's Multiple Intelligence. Hasil penelitian tersebut menunjukkan bahwa model Project-Based Learning efektif meningkatkan prestasi belajar mahahasiswa, memperoleh pengetahuan melalui pembelajaran aktif, memperoleh pengetahuan interdisipliner dan multidisipliner, meningkatkan tanggung jawab untuk belajar, memperoleh keterampilan komunikasi dalam pengambilan keputusan, dan meningkatkan kepercayaan diri mahasiswa. Cynthia dan Shannon (2013) dalam penelitiaanya tentang Project-Based Learning and Student Engagement. Hasil penelitian ini menyatakan bahwa penggunaan model Project-Based Learning membuat keterlibatan prilaku siswa menurun. Namun, keterlibatan kognitif mahasiswa meningkat secara signifikan.

Bertolak dari uraian tersebut di atas, maka peneliti merasa perlu adanya penggunaan model pembelajaran berbasis proyek dalam pembelajaran menulis artikel opini pada mahasiswa studi Pendidikan Bahasa dan Sastra Indonesia, Fakultas Keguruan dan Ilmu Pendidikan, Universitas Muhammadiyah Makassar. Penggunaan model pembelajaran berbasis proyek tersebut, diharapkan agar semua masalah yang dihadapi dalam pembelajaran menulis artikel opini dapat teratasi.

\section{METODE PENELITIAN}

Penelitian ini merupakan penelitian eksperimen yang dimaksudkan untuk mengetahui ada tidaknya akibat dari sesuatu yang perlakuan (treatmen) pada subjek yang di teliti. Penelitian eksperimen adalah penelitian yang dilakukan dengan mengadakan manipulasi terhadap objek penelitian serta diadakannya kontrol terhadap variabel tertentu untuk mengetahui ada tidaknya hubungan sebab akibat (Arikunto, 2010). Rancangan penelitian yang digunakan dalam 
penelitian ini adalah "one groups pretest-posttest design", yaitu rancangan penelitian eksperimen yang terdapat pretest sebelum diberi perlakuan dan posttest setelah diberi perlakuan (Sugiyono, 2010: 112).

Adapun tahapan-tahapan penelitian pada penelitian ini, yaitu: (1) kegiatan Awal (pretes). Kegiatan awal dilakukan sebelum tindakan (treatment) dengan tujuan mengetahui kemampuan awal mahasiswa dalam menulis artikel opini sebelum diberikan tindakan (treatmen), (2) perlakuan (treatment). Pembelajaran dilakukan selama tiga kali pertemuan, dan (3) kegiatan Akhir (postest). Postest dilakukan setelah pembelajaran selesai. Penelitian ini dilaksanakan di Kampus Universitas Muhammadiyah Makassar, Jalan Sultan Alauddin No.259, Makassar.

Untuk memperoleh data pada penelitian ini digunakan instrumen. Instrumen yang digunakan yaitu observasi dan tes. Teknik yang digunakan untuk mengumpulkan data penelitian ini adalah teknik observasi dan tes. Observasi dilakukan guna memperoleh gambaran dan kondisi awal pembelajaran menulis artikel opini. Sementara, teknik tes yaitu tes menulis artikel opini. Dalam pelaksanaannya, mahasiswa diberikan tugas menulis artikel opini. Data penelitian dianalisis dengan analisis statistik deskriptif dan inferensial.

\section{HASIL DAN PEMBAHASAN \\ HASIL PENELITIAN}

\section{Deskripsi hasil belajar mahasiswa dalam pembelajaran menulis artikel opini tanpa menggunakan model pembelajaran berbasis proyek pada pretest}

Hasil analisis statistik deskriptif hasil belajar mahasiswa dalam pembelajaran menulis artikel opini tanpa menggunakan model pembelajaran berbasis proyek pada pretest menunjukkan bahwa nilai tertinggi yang diperoleh adalah 89 yang diperoleh 1 orang mahasiswa $(3,3 \%)$ dan nilai terendah adalah 53 yang diperoleh 1 orang mahasiswa (3,3\%). Selanjutnya, mahasiswa yang memperoleh nilai 60.00 berjumlah 1 orang (3.3\%), mahasiswa yang memperoleh nilai 63.00 berjumlah 1 orang (3.3\%), mahasiswa yang memperoleh nilai 68.00 berjumlah 2 orang $(6.7 \%)$, mahasiswa yang memperoleh nilai 70.00 berjumlah 2 orang $(6.7 \%)$, mahasiswa yang memperoleh nilai 71.00 berjumlah 2 orang (6.7\%), mahasiswa yang memperoleh nilai 72.00 berjumlah 3 orang (10.0\%), mahasiswa yang memperoleh nilai 73.00 berjumlah 2 orang (6.7\%), mahasiswa yang memperoleh nilai 74.00 berjumlah 1 orang (3.3\%), mahasiswa yang memperoleh nilai 77.00 berjumlah 2 orang $(6.7 \%)$, mahasiswa yang memperoleh nilai 78.00 berjumlah 3 orang (10.0\%), mahasiswa yang memperoleh nilai 79.00 berjumlah 1 orang (3.3\%), mahasiswa yang memperoleh nilai 80.00 berjumlah 1 orang (3.3\%), mahasiswa yang memperoleh nilai 82.00 berjumlah 1 orang $(3.3 \%)$, mahasiswa yang memperoleh nilai 83.00 berjumlah 1 orang (3.3\%), mahasiswa yang memperoleh nilai 84.00 berjumlah 2 orang (6.7\%), mahasiswa yang memperoleh nilai 86.00 berjumlah 1 orang $\quad(3.3 \%)$, dan mahasiswa yang memperoleh nilai 87.00 berjumlah 2 orang $(6.7 \%)$. 
Apabila hasil belajar mahasiswa dalam pembelajaran menulis artikel opini tanpa menggunakan model pembelajaran berbasis proyek pada pretest diilustrasikan ke dalam grafik frekuensi dan hasil belajar, tampak seperti berikut ini.

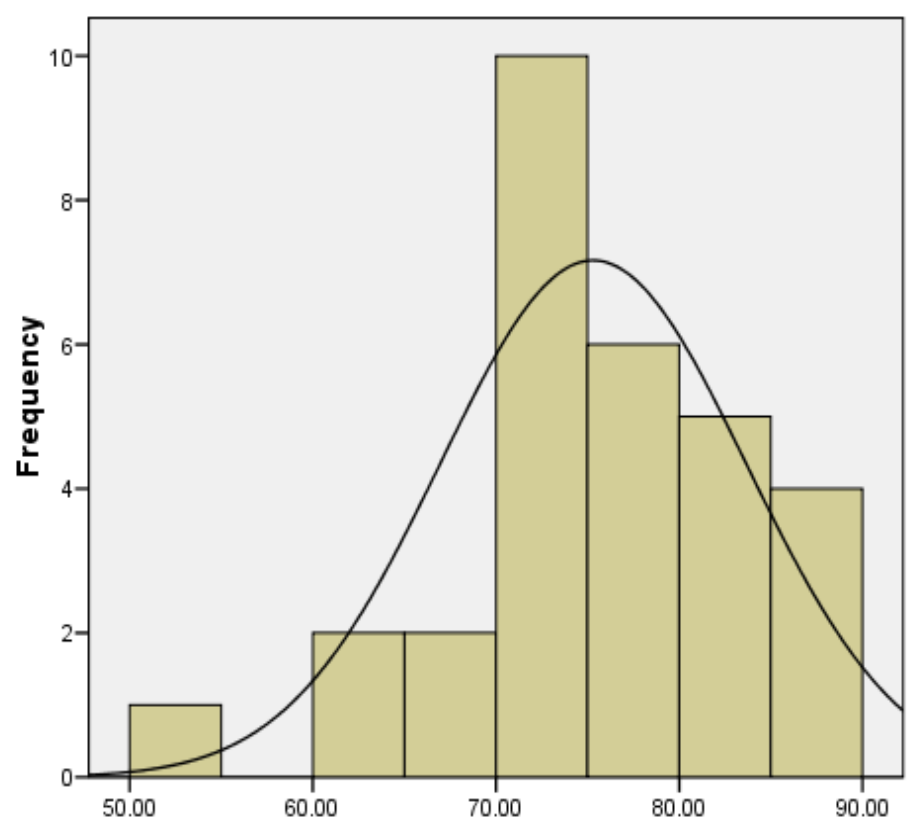

Grafik 1 Frekuensi dan Hasil Belajar Mahasiswa pada Pretest

\section{Deskripsi hasil belajar mahasiswa dalam pembelajaran menulis artikel opini dengan menggunakan model pembelajaran berbasis proyek pada postest}

Hasil analisis statistik deskriptif hasil belajar mahasiswa dalam pembelajaran menulis artikel opini dengan menggunakan model pembelajaran berbasis proyek pada postest menunjukkan bahwa nilai tertinggi yang diperoleh adalah 97 yang diperoleh 1 orang $(2,3 \%)$ dan nilai terendah adalah 70 yang diperoleh 1 orang $(3,3 \%)$. Selanjutnya, mahasiswa yang memperoleh nilai 71.00 berjumlah 1 orang (3.3\%), mahasiswa yang memperoleh nilai 73.00 berjumlah 1 orang $(3.3 \%)$, mahasiswa yang memperoleh nilai 76.00 berjumlah 1 orang $(3.3 \%)$, mahasiswa yang memperoleh nilai 79.00 berjumlah 1 orang (3.3\%), mahasiswa yang memperoleh nilai 80.00 berjumlah 4 orang (13.3\%), mahasiswa yang memperoleh nilai 81.00 berjumlah 3 orang (10.0\%), mahasiswa yang memperoleh nilai 83.00 berjumlah 1 orang (3.3\%), mahasiswa yang memperoleh nilai 85.00 berjumlah 2 orang (6.7\%), mahasiswa yang memperoleh nilai 87.00 berjumlah 2 orang (6.7\%), mahasiswa yang memperoleh nilai 88.00 berjumlah 1 orang (3.3\%), mahasiswa yang memperoleh nilai 89.00 berjumlah 3 orang (10.0\%), mahasiswa yang memperoleh nilai 90.00 berjumlah 2 orang $(6.7 \%)$, mahasiswa yang memperoleh nilai 91.00 berjumlah 2 orang $(6.7 \%)$, mahasiswa 
yang memperoleh nilai 92.00 berjumlah 3 orang (10.0\%), dan mahasiswa yang memperoleh nilai 94.00 berjumlah 1 orang $(3.3 \%)$.

Apabila hasil belajar mahasiswa dalam pembelajaran menulis artikel opini dengan menggunakan model pembelajaran berbasis proyek pada postest diilustrasikan ke dalam grafik frekuensi dan hasil belajar, tampak seperti berikut ini.

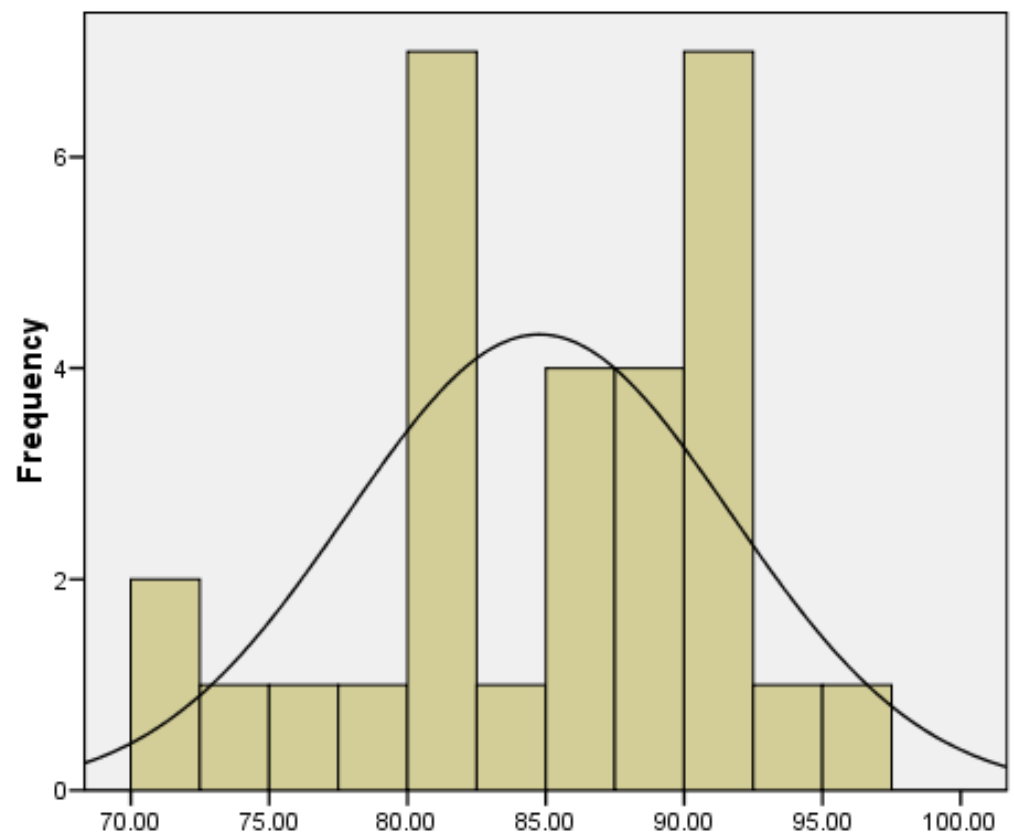

Grafik 2 Frekuensi dan Hasil Belajar Mahasiswa pada Postest

\section{Deskripsi keefektifan model pembelajaran berbasis proyek dalam pembelajaran menulis artikel opini}

Uji normalitas hasil belajar mahasiswa dalam pembelajaran menulis artikel opini tanpa menggunakan dan menggunakan model pembelajaran berbasis proyek dilakukan dengan uji statistic lilliefors (Kolmogorov-Smirnov) dengan ketentuan jika $\mathrm{p}>0,05$, maka data dinyatakan berdistribusi normal, namun jika $\mathrm{p}<0,05$ maka hasil belajar dinyatakan tidak berdistribusi normal. Hasil uji normalitas hasil belajar mahasiswa dalam pembelajaran menulis artikel opini tanpa menggunakan dan menggunakan model pembelajaran berbasis proyek menunjukkan bahwa nilai $p=0,96$ dengan signifikansi $=0$, 200 untuk hasil belajar mahasiswa dalam pembelajaran menulis artikel opini tanpa menggunakan model pembelajaran berbasis proyek dan $p=0,129$ dengan signifikansi 0, 200 untuk hasil belajar mahasiswa dalam pembelajaran menulis artikel opini dengan menggunakan model pembelajaran berbasis proyek. Hal ini menunjukkan bahwa $p>\alpha=0,05$.

Selanjutnya, uji homogenitas hasil belajar mahasiswa dalam pembelajaran menulis artikel opini tanpa menggunakan dan menggunakan model pembelajaran 
berbasis proyek dilakukan dengan uji statistic test of homogeneity of variances dengan ketentuan jika signifikansi $\mathrm{p}>$ 0,05 maka data dinyatakan homogen, namun jika signifikansi $\mathrm{p}<0,05$ maka hasil belajar dinyatakan tidak homogen. Hasil uji homogenitas hasil belajar mahasiswa dalam pembelajaran menulis artikel opini tanpa menggunakan dan menggunakan model pembelajaran berbasis proyek menunjukkan bahwa nilai $p=0,560$ dengan signifikansi $=0,457$. Hal ini, menunjukkan bahwa $p>\alpha=0,05$. Ini berarti, hasil belajar mahasiswa dalam pembelajaran menulis artikel opini tanpa menggunakan dan menggunakan model pembelajaran berbasis proyek dinyatakan homogen.

Sementara, Uji t data hasil belajar mahasiswa dalam pembelajaran menulis artikel opini tanpa menggunakan dan menggunakan model pembelajaran berbasis proyek dilakukan dengan uji independent samples test dengan ketentuan jika nilai $\mathrm{p}>0,05$ maka dinyatakan hopotesis diterima, namun jika $\mathrm{p}<0,05$ maka dinyatakan hopotesis ditolak. Hasil uji test menunjukkan bahwa nilai $\mathrm{t}$ hitung yang diperoleh adalah $=4,779$ sedangkan $t_{\text {tabel }}$ dengan taraf signifikasin 0,05 adalah $=2,023$.

\section{PEMBAHASAN}

Pada bagian ini, diuraikan pembahasan hasil penelitian yang meliputi: hasil belajar mahasiswa dalam pembelajaran menulis artikel opini tanpa menggunakan model model pembelajaran berbasis proyek pada pretest, hasil belajar mahasiswa dalam pembelajaran menulis artikel opini dengan menggunakan model model pembelajaran berbasis proyek pada posttest, dan keefektifan model pembelajaran berbasis proyek dalam pembelajaran menulis artikel opini. Pembahasan tersebut, diuraikan sebagai berikut.

Hasil belajar mahasiswa dalam pembelajaran menulis artikel opini tanpa menggunakan model pembelajaran berbasis proyek pada pretest menunjukkan bahwa: mahasiswa yang memperoleh hasil belajar $(\geq 75-\leq 100)$ berjumlah 15 orang $(50 \%)$ dan mahasiswa yang memperoleh hasil belajar $(0-<75)$ berjumlah 15 orang $(50 \%)$. Dengan demikian, dapat dinyatakan bahwa hasil belajar mahasiswa dalam pembelajaran menulis artikel opini tanpa menggunakan model pembelajaran berbasis proyek pada pretest berada pada kategori tidak tuntas karena persentase hasil belajar mahasiswa yang tuntas belum mencapai standar ketuntasan hasil belajar, yakni ( $\geq 85 \%$ - 100\%).

Hasil belajar mahasiswa dalam pembelajaran menulis artikel opini dengan menggunakan model pembelajaran berbasis proyek pada posttest menunjukkan bahwa: mahasiswa yang memperoleh hasil belajar $(\geq 75-\leq 100)$ berjumlah 27 orang $(90 \%)$ dan mahasiswa yang memperoleh hasil belajar $(0-<75)$ berjumlah 15 orang (50\%). Dengan demikian, dapat disimpulkan bahwa hasil belajar mahasiswa dalam pembelajaran menulis artikel opini dengan menggunakan model pembelajaran berbasis proyek pada postest berada pada kategori tuntas karena persentase hasil belajar mahasiswa yang tuntas telah mencapai standar ketuntasan hasil belajar, yakni $(\geq 85 \%-100 \%)$.

Uji t data hasil belajar mahasiswa menunjukkan bahwa nilai $\mathrm{t}$ hitung yang diperoleh adalah $=4,779$ sedangkan $t_{\text {tabel }}$ dengan taraf signifikasin 0,05 adalah $=$ 
2,023. Bedasarkan hasil uji hipotesis dengan statistik inferensial (t-test) independent samples test tersebut, dinyatakan bahwa nilai $\mathrm{t}_{\text {hitung }}>$ nilai $\mathrm{t}_{\text {tabel }}(4$, $779>2,023)$, artinya model pembelajaran berbasis proyek efektif digunakan dalam pembelajaran menulis artikel opini pada Program Studi Pendidikan Bahasa dan Sastra Indonesia Universitas Muhammadiyah Makassar.

\section{KESIMPULAN}

Berdasarkan analisis data hasil penelitian, dapat disimpulkan hasil pada penelitian ini, yaitu: (1) Hasil belajar mahasiswa dalam pembelajaran menulis artikel opini tanpa menggunakan model pembelajaran berbasis proyek pada pretest berada pada kategori tidak tuntas karena persentase hasil belajar mahasiswa yang tuntas belum mencapai standar ketuntasan hasil belajar, yakni ( $\geq 85 \%$ - 100\%), (2) hasil belajar mahasiswa dalam pembelajaran menulis artikel opini dengan menggunakan model pembelajaran berbasis proyek pada postest berada pada kategori tuntas karena persentase hasil belajar mahasiswa yang tuntas telah mencapai standar ketuntasan hasil belajar, yakni $(\geq 85 \%-100 \%)$, dan (3) Model pembelajaran berbasis proyek efektif digunakan dalam pembelajaran pembelajaran menulis artikel opini pada Program Studi Pendidikan Bahasa dan Sastra Indonesia Universitas Muhammadiyah Makassar karena kriteria keefektifan telah terpenuhi, yaitu nilai $\mathrm{t}_{\text {hitung }}>$ nilai $\mathrm{t}_{\text {tabel }}(4,779>2,04)$.

\section{DAFTAR PUSTAKA}

Abidin, Yunus. 2014. Desain Sistem Pembelajaran dalam Konteks Kurikulum 2013. Bandung: PT. Refika Aditama.

Arikunto, Suharsimi. 2010. Prosedur Penelitian: Suatu Pendekatan Praktik. Jakarta: PT. Rineka Cipta.

Cynthia dan Shannon. 2013. Project-Based Learning and Student Engagement. Journal Academic Research International.

Daryanto. 2005. Kamus Bahasa Indonesia Lengkap. Surabaya: PT Apollo.

Dimyati dan Mudjiono. 2013. Belajar dan Pembelajaran. Jakarta: PT Rineka Cipta.

Finoza. Lamuddin 2010. Komposisi Bahasa Indonesia. Jakarta: Insan Mulia.

Hosnan. 2014. Pendekatan Saintifik Dan Kontekstual Dalam Pembelajaran Abad 21. Jakarta : Ghalia Indonesia

Kurzel, Frank and Rath, Michelle. 2007. Project-Based Learning and Learning Enviroments. Journal Issues in Informing Science and Information Technology.

Kusmayadi, Ismail. 2007. Menulis dengan Hati Membangun Motivasi Menulis. Bandung: PT. Pribumi Mekar.

Ngalimun. 2013. Strategi dan Model Pembelajaran. Yogyakarta: Aswaja Pressindo. 
Nurgiyantoro, Burhan. 2012. Penilaian dalam Pengajaran Bahasa dan Sastra. Yogyakarta: BPFE.

Pranata, Xavier Quentin. 2002. Menulis dengan Cin\#ta: Belajar Mandiri dan Mengajarkan Kembali Jurnalisme Kasih Sayang. Yogyakarta: Yayasan Andi.

Rizam, Maghfirah Masyithah. 2015. Penalaran dalam Artikel Rubrik Opini Surat Kabar Harian Jawa Pos. Kembara: Jurnal Keilmuan Bahasa, Sastra, dan Pengajarannya.

Saddhono dan Slamet. 2012. Meningkatkan Keterampilan Berbahasa Indonesia :Teori dan Aplikasi. Bandung: Karya Putra Darwat..

Sugiyono. 2010. Metode Penelitian Pendidikan Pendekatan Kuantitatif, Kualitatif, dan R\&D. Bandung. Alfabeta.

Sukmadinata, Nana Syaodih. 2008. Metode Penelitian Pendidikan. Bandung: PT Remaja Rosdakarya.

Suparno dan Yunus. 2011. Keterampilan Dasar Menulis. Jakarta : Universitas Terbuka.

Sumadiria, AS Haris. 2004. Jurnalistik Indonesia, Menulis Berita dan Feature. Bandung : PT. Refika Aditama.

Syarif, Elina, dkk. 2009. Pembelajaran Menulis. Jakarta: Departemen Pendidikan Nasional.

Tarigan, Henry Guntur. 2010. Menulis sebagai Suatu Keterampilan Berbahasa. Bandung: Angkasa.

Tiantong M, Siksen S. 2013. The Online Project-Based Learning Model Based on Student's Multiple Intelligence. Journal of Humanities and Social Science.

Tartono, S. 2005. Menulis di Media Massa Gampang. Yogyakarta: Yayasan Pustaka Nusantama.

Warsono dan Hariyanto. 2012. Pembelajaran Aktif Teori dan Asesmen. Bandung: Remaja Rosda Karya.

Wena, Made .2009. Strategi Pembelajaran Inovatif Kontemporer. Jakarta: Bumi Aksara.

Wibowo, Wahyu. 2006. Berani Menulis Artikel. Jakarta:Gramedia Pustaka Utama 